\title{
Screening for alcohol-related liver damage in the community: findings from the PrevAlL (Preventing Alcohol Harm in Liverpool) Study
}

\author{
Penny A Cook ${ }^{1 *}$, Michela Morleo ${ }^{2}$, David Billington ${ }^{3}$, Mark Gabbay ${ }^{4}$, Nick Sheron ${ }^{5}$, lan T Gilmore ${ }^{6}$, Mark A Bellis ${ }^{2}$ \\ From International Network on Brief Interventions for Alcohol and Other Drugs (INEBRIA) Meeting 2013 \\ Rome, Italy. 18-20 September 2013
}

Progression of alcohol-related liver fibrosis stops when drinking stops, but the diagnosis is usually missed because the process of fibrosis is symptom free and missed by the usual liver function tests. Non-invasive tests to detect fibrosis and cirrhosis are available, but not currently used in primary care. We aimed to: identify optimal ways of engaging communities with liver disease screening; to inform a future trial to augment brief interventions with a liver risk score; and to estimate the prevalence of liver disease. Participants, aged 36-55y, registered with general practice (GP) or working in Merseyside, UK, were contacted by post (GP) or through workplaces. Risky drinkers (previous week drinking $>112 \mathrm{~g}$ females/168g males) were invited for a liver screen. Blood samples were tested for fibrosis markers (hyaluronic acid and procollagen type III $\mathrm{N}$-terminal peptide) and categorised using the Simple Traffic Light (STL) algorithm. Of 6439 GP registrants, $539(8 \%)$ returned the alcohol consumption questionnaire; 152 were risky drinkers and were invited for liver screening, and 27 attended. Screening in the 13 participating workplaces (out of 37 approached) was attended by $2-6 \%$ of the eligible workforce $(n=363)$. Of 142 risky drinkers, most (91\%) accepted the liver screening test. In total, seven samples were graded 'red', yielding a prevalence of $4.6 \%(95 \%$ CI $2.02-9.14 \%)$ of probable liver disease and further 26.3\% (20.0-33.7\%; 41 samples) scored 'amber' (moderate risk). Detecting and supporting cases in the community could avert deaths and save costs, and this work informs development of a trial to determine whether feedback of liver disease risk scores is more effective than brief intervention alone. We conclude that workplaces are optimum sites, because screening takes place at a time and

\footnotetext{
* Correspondence: p.a.cook@salford.ac.uk

${ }^{1}$ School of Health Sciences, University of Salford, Greater Manchester, UK

Full list of author information is available at the end of the article
}

location that was convenient for participants; however alternative methods will be required to access those who do not work, whose risk may be higher.

\section{Authors' details \\ ${ }^{1}$ School of Health Sciences, University of Salford, Greater Manchester, UK. ${ }^{2}$ Centre for Public Health, Liverpool John Moores University, Liverpool, UK. ${ }^{3}$ School of Biomolecular Sciences, Liverpool John Moores University, Liverpool, UK. ${ }^{4}$ Health Services Research, University of Liverpool, Liverpool, UK. ${ }^{5}$ Medical School, University of Southampton, Southampton, UK. ${ }^{6}$ Royal Liverpool University Hospital, Liverpool, UK.}

Published: 4 September 2013

doi:10.1186/1940-0640-8-S1-A18

Cite this article as: Cook et al.: Screening for alcohol-related liver damage in the community: findings from the PrevAlL (Preventing Alcohol Harm in Liverpool) Study. Addiction Science \& Clinical Practice 2013 8(Suppl 1):A18.

Submit your next manuscript to BioMed Central and take full advantage of:

- Convenient online submission

- Thorough peer review

- No space constraints or color figure charges

- Immediate publication on acceptance

- Inclusion in PubMed, CAS, Scopus and Google Scholar

- Research which is freely available for redistribution

Submit your manuscript at www.biomedcentral.com/submit

\section{() Biomed Central}

